\title{
The Extent of Ventilator-Induced Lung Injury in Mice Partly Depends on Duration of Mechanical Ventilation
}

\author{
Maria A. Hegeman, ${ }^{1}$ Sabrine N. T. Hemmes, ${ }^{1}$ Maria T. Kuipers, ${ }^{1}$ \\ Lieuwe D. J. Bos, ${ }^{1}$ Geartsje Jongsma, ${ }^{1}$ Joris J. T. H. Roelofs, ${ }^{2}$ Koenraad F. van der Sluijs, ${ }^{1}$ \\ Nicole P. Juffermans, ${ }^{1,3}$ Margreeth B. Vroom, ${ }^{3}$ and Marcus J. Schultz ${ }^{1,3}$ \\ ${ }^{1}$ Laboratory of Experimental Intensive Care and Anesthesiology (LEICA), Academic Medical Center, Meibergdreef 9 , \\ 1105 AZ Amsterdam, The Netherlands \\ ${ }^{2}$ Department of Pathology, Academic Medical Center, Meibergdreef 9, 1105 AZ Amsterdam, The Netherlands \\ ${ }^{3}$ Department of Intensive Care, Academic Medical Center, Meibergdreef 9, 1105 AZ Amsterdam, The Netherlands
}

Correspondence should be addressed to Maria A. Hegeman; jessica.hegeman@gmail.com

Received 10 January 2013; Revised 15 March 2013; Accepted 17 March 2013

Academic Editor: Djillali Annane

Copyright (C) 2013 Maria A. Hegeman et al. This is an open access article distributed under the Creative Commons Attribution License, which permits unrestricted use, distribution, and reproduction in any medium, provided the original work is properly cited.

Background. Mechanical ventilation (MV) has the potential to initiate ventilator-induced lung injury (VILI). The pathogenesis of VILI has been primarily studied in animal models using more or less injurious ventilator settings. However, we speculate that duration of MV also influences severity and character of VILI. Methods. Sixty-four healthy C57Bl/6 mice were mechanically ventilated for 5 or 12 hours, using lower tidal volumes with positive end-expiratory pressure (PEEP) or higher tidal volumes without PEEP. Fifteen nonventilated mice served as controls. Results. All animals remained hemodynamically stable and survived MV protocols. In both $\mathrm{MV}$ groups, $\mathrm{PaO}_{2}$ to $\mathrm{FiO}_{2}$ ratios were lower and alveolar cell counts were higher after 12 hours of MV compared to 5 hours. Alveolar-capillary permeability was increased after 12 hours compared to 5 hours, although differences did not reach statistical significance. Lung levels of inflammatory mediators did not further increase over time. Only in mice ventilated with increased strain, lung compliance declined and wet to dry ratio increased after 12 hours of MV compared to 5 hours. Conclusions. Deleterious effects of MV are partly dependent on its duration. Even lower tidal volumes with PEEP may initiate aspects of VILI after 12 hours of MV.

\section{Introduction}

Increased strain due to mechanical ventilation (MV) has the potential to aggravate existing lung injury [1]. Indeed, one meta-analysis shows intensive care unit (ICU) patients with acute respiratory distress syndrome (ARDS) to benefit from $M V$ with lower tidal volume $V_{\mathrm{T}}$ [2]. $M V$ with too high $\mathrm{V}_{\mathrm{T}}$ even has the potential to induce lung injury [3]. This is confirmed in a more recent meta-analysis that shows patients without ARDS at onset of MV to benefit from MV with lower $\mathrm{V}_{\mathrm{T}}$ as well [4]. Importantly, this meta-analysis also showed beneficial effects of lower $\mathrm{V}_{\mathrm{T}}$ in patients receiving MV during general anesthesia for surgery [4].

The potential of MV to aggravate or initiate lung injury was originally proposed in animal models and focused merely on size of $\mathrm{V}_{\mathrm{T}}$. Indeed, the so-called ventilator-induced lung injury (VILI) was demonstrated in models of MV in animals with injured lungs [5]. These models revealed that use of high $V_{T}$ worsened the proinflammatory response, disturbed alveolar fibrin turnover, and increased alveolarcapillary permeability resulting in accumulation of proteinrich edema and finally loss of pulmonary function. VILI was also observed in ventilated animals with noninjured lungs [6-10], confirming clinical studies, which suggest that conventional MV has the capability to initiate lung injury by itself. Most interestingly, even MV with lower $\mathrm{V}_{T}$ is recently found to induce VILI in healthy animals [11-13].

Animal models with variable durations of MV are important for preclinical testing of ventilator settings, as duration of surgical procedures may vary significantly. Moreover, 
a vast number of patients may need additional postoperative MV, especially after major surgery. Although the evolution of VILI has been studied even beyond 24 hours in large animal models $[14,15]$, studies testing the effect of duration of MV on development of VILI are limited in smaller animals like mice. One important advantage of mice above larger animals is the possible application of transgenic or knockout models. Therefore, the aim of the present study was to compare the effects after 12 hours of MV with those after 5 hours in an established model of VILI in healthy mice, that is, without preexisting lung injury. Different $\mathrm{V}_{\mathrm{T}}$ and positive end-expiratory pressure (PEEP) levels were used to create two opposing ventilation strategies, a strategy with lower $\mathrm{V}_{\mathrm{T}}$ and PEEP $\left(\mathrm{LV}_{\mathrm{T}} / \mathrm{PEEP}\right)$ or a strategy with higher $\mathrm{V}_{\mathrm{T}}$ and zero PEEP $\left(\mathrm{HV}_{\mathrm{T}} / \mathrm{ZEEP}\right)$. We hypothesized that the deleterious effects of MV are not only dependent on its strategy but also on its duration.

\section{Methods}

2.1. Approval. The animal care and use committee of the Academic Medical Center, Amsterdam, the Netherlands, approved all experiments. Animal handling was in accordance with institutional standards for care and use of laboratory animals.

2.2. Animals. Seventy-nine male $\mathrm{C} 57 \mathrm{Bl} / 6$ mice (26-30 grams) were randomly assigned to different experimental groups. Sixty-four mice were randomized to MV and fifteen mice were randomized to nonventilated controls (NVC). All mice were without preexisting lung injury at time of randomization.

2.3. Animal Handling. Mice received an intraperitoneal bolus of $1 \mathrm{~mL} 0.9 \%$ saline. After 1 hour, mice were randomized to MV or NVC. Mice that were randomized to MV received an induction of anesthesia via intraperitoneal injection of a mix containing $126 \mathrm{mg} / \mathrm{kg}$ ketamine (Eurovet Animal Health B.V., Bladel, the Netherlands), $0.1 \mathrm{mg} / \mathrm{kg}$ dexmedetomidine (Pfizer Animal Health B.V., Capelle aan den IJssel, the Netherlands) and $0.5 \mathrm{mg} / \mathrm{kg}$ atropine (Pharmachemie, Haarlem, the Netherlands). Maintenance anesthesia was administered via an intraperitoneal cathether every hour and consisted of $36 \mathrm{mg} / \mathrm{kg}$ ketamine, $0.02 \mathrm{mg} / \mathrm{kg}$ dexmedetomidine and $0.075 \mathrm{mg} / \mathrm{kg}$ atropine. Sodium bicarbonate was administered via an intraperitoneal cathether every 30 minutes to maintain bicarbonate levels within the physiological range (22$26 \mathrm{mM}$ ). No muscle relaxants were used. Body temperature was kept between 36.5 and $37.5^{\circ} \mathrm{C}$.

2.4. Mechanical Ventilation. After insertion of a tracheotomy tube $(1.3 \mathrm{~mm}$ outer diameter and $0.8 \mathrm{~mm}$ inner diameter), mice were connected to a Babylog 8000 plus ventilator (Draeger Medical, Lubeck, Germany) and mechanically ventilated for 5 or 12 hours using a pressure-controlled, volume-targeted approach, at a fractional inspired oxygen concentration $\left(\mathrm{FiO}_{2}\right)$ of 0.5 and an inspiration-to-expiration ratio of $1: 3$. A pneumotachograph was used for monitoring and continuous regulation of $\mathrm{V}_{\mathrm{T}}$ (capillary tube, PTM T16375; HSE-Harvard Apparatus, March-Hugstetten, Germany). $\mathrm{V}_{\mathrm{T}}$ was recorded using respiration software (HSEBDAS basic data acquisition, HSE-Harvard Apparatus); delivered pressure was regularly adapted to deliver target $\mathrm{V}_{\mathrm{T}}$.

2.5. Study Groups. Mice that were randomized to MV were mechanically ventilated with lower $\mathrm{V}_{\mathrm{T}}(\sim 7 \mathrm{~mL} / \mathrm{kg})$ and PEEP of $3 \mathrm{cmH}_{2} \mathrm{O}\left(\mathrm{LV}_{\mathrm{T}} / \mathrm{PEEP}\right)$ or with higher $\mathrm{V}_{\mathrm{T}}(\sim 15 \mathrm{~mL} / \mathrm{kg})$ and PEEP of $0 \mathrm{cmH}_{2} \mathrm{O}\left(\mathrm{HV}_{\mathrm{T}} / \mathrm{ZEEP}\right)$. Respiratory rate was set at 160 or 52 breaths per minute, respectively, aiming at normal $\mathrm{pH}$ (7.35-7.45). A recruitment maneuver was performed every 30 minutes during $\mathrm{LV}_{\mathrm{T}} / \mathrm{PEEP}$ and every 60 minutes during $\mathrm{HV}_{\mathrm{T}}$ /ZEEP by applying an inspiratory hold for 5 seconds, with increased inspiratory pressures when necessary, aiming at normal $\mathrm{PaCO}_{2}(35-45 \mathrm{mmHg})$. The last recruitment maneuver was performed 30 or 60 minutes before blood sampling ( $\mathrm{LV}_{\mathrm{T}} / \mathrm{PEEP}$ and $\mathrm{HV}_{\mathrm{T}} / \mathrm{ZEEP}$, resp.), which was similar in mice ventilated for 5 or 12 hours.

2.6. Monitoring. Systolic blood pressure and heart rate were noninvasively monitored using a tail-cuff system for mice (ADInstruments, Spenbach, Germany). Peripheral oxygen saturation $\left(\mathrm{SpO}_{2}\right)$ was noninvasively measured using a pulse oximeter applied to the mouse hind paw (Siemens Medical Systems, Danvers, MA, USA). After 5 or 12 hours of MV, arterial blood was taken from the carotid artery for blood gas analysis (RAPIDPoint 405; Siemens Healthcare Diagnostics, Tarrytown, NY, USA).

Compliance of the respiratory system was calculated using $C_{\text {stat }}=\mathrm{V}_{\mathrm{T}} /\left(P_{\text {plat }}-\mathrm{PEEP}\right)$, in which $C_{\text {stat }}$ is the static compliance $\left(\mathrm{mL} / \mathrm{cmH}_{2} \mathrm{O}\right)$, and $P_{\text {plat }}$ is the plateau pressure $\left(\mathrm{cmH}_{2} \mathrm{O}\right) . \mathrm{V}_{\mathrm{T}}$ was determined using the pneumotachograph. $P_{\text {plat }}$ and PEEP were displayed on the mechanical ventilator. The respiration software revealed a decelerating flow curve during both inspiration and expiration, and a square-wave pressure curve (hourly monitored).

2.7. Lung Tissue. Lung tissue was harvested and processed as previously described $[13,16]$. From a first series of mice ( $n=6-8$ per group), the right lung was used to obtain bronchoalveolar lavage fluid (BALF) and the left lung was used for wet to dry ratios. From a second series of mice $(n=$ 6-8 per group), the right lung was snap frozen to obtain lung homogenates and the left lung used for histopathology.

2.8. Assays. Interleukin (IL)-1 $\beta$, IL-6, keratinocyte-derived chemokine $(\mathrm{KC})$, and macrophage inflammatory protein(MIP)-2 levels were measured in total lung homogenates and receptor for advanced glycation endproducts (RAGE) levels were measured in BALF by ELISA (R\&D systems, Minneapolis, MN, USA). Total protein levels were determined in BALF using a Bradford Protein Assay Kit according 
TABLE 1: Ventilator settings and arterial blood gas analysis.

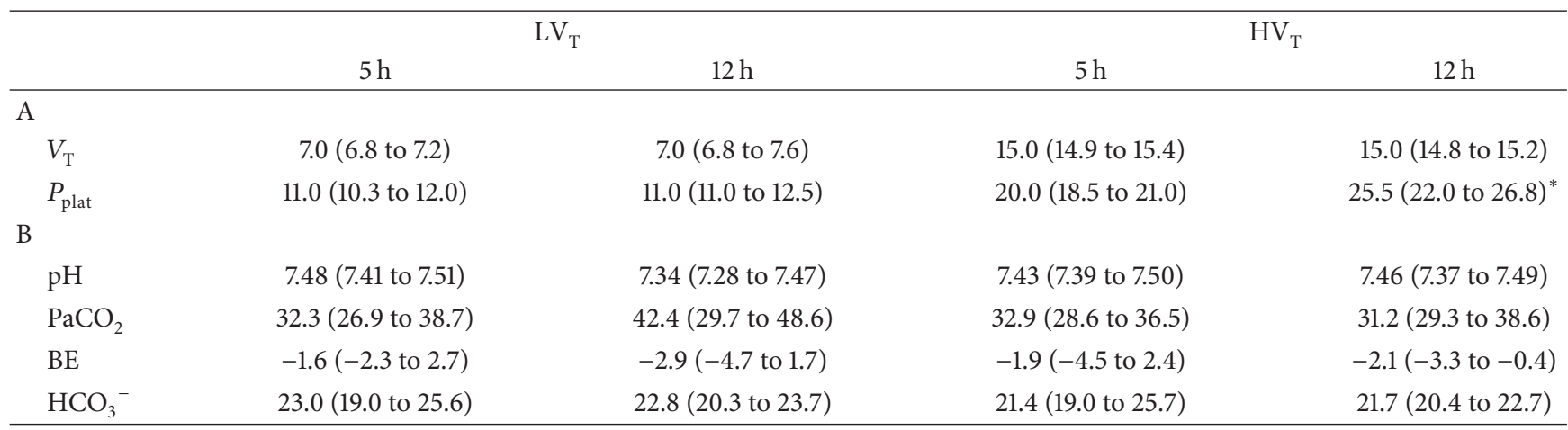

$\mathrm{LV}_{\mathrm{T}}, \mathrm{HV}_{\mathrm{T}}=$ ventilation with $\mathrm{LV}_{\mathrm{T}} / \mathrm{PEEP}$ or $\mathrm{HV}_{\mathrm{T}} / \mathrm{ZEEP}$ settings; $5 \mathrm{~h}, 12 \mathrm{~h}=5$ or 12 hours of ventilation; $V_{\mathrm{T}}=$ tidal volume in $\mathrm{mL} / \mathrm{kg} ; P_{\text {plat }}=$ plateau pressure in $\mathrm{cmH}_{2} \mathrm{O} ; \mathrm{PaCO}_{2}=$ partial pressure of arterial carbon dioxide in $\mathrm{mmHg} ; \mathrm{BE}=$ base excess in mmol/L; $\mathrm{HCO}_{3}{ }^{-}=$bicarbonate in mmol/L. Data are presented as median (IQR) of 4-8 (A) or 11-15 (B) mice per group. ${ }^{*}$ Illustrates primary statistical analysis $\left({ }^{*} P<0.05\right.$ versus 5 hours).

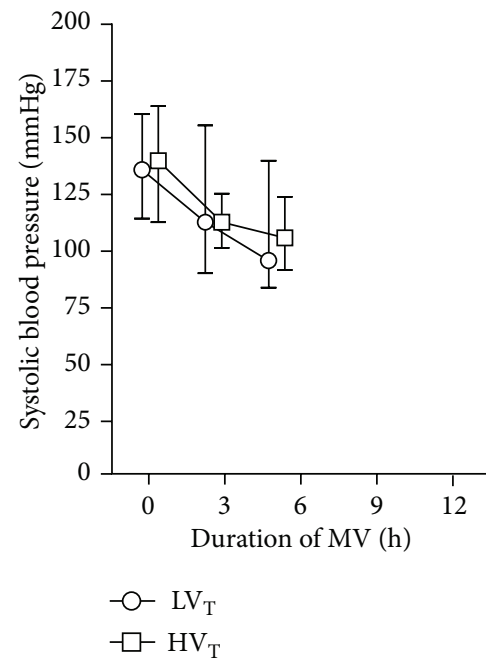

(a)

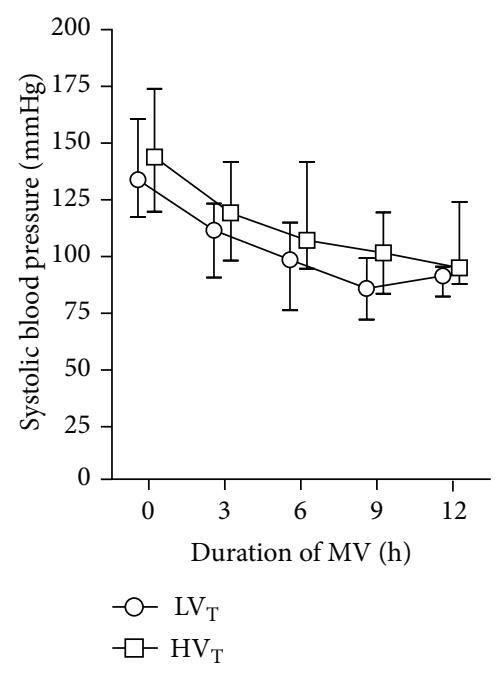

(d)

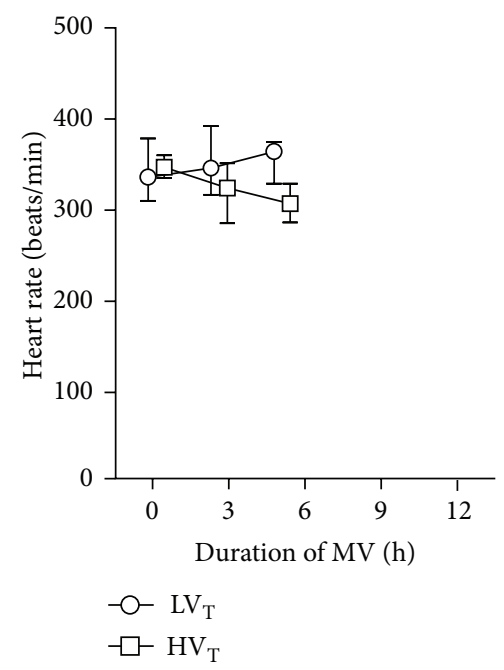

(b)

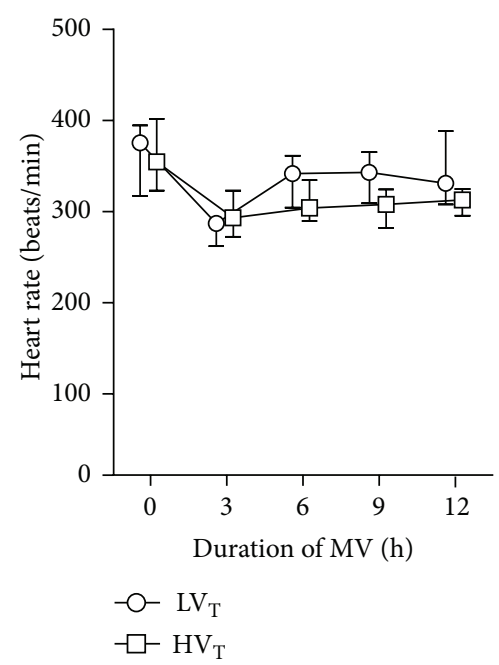

(e)

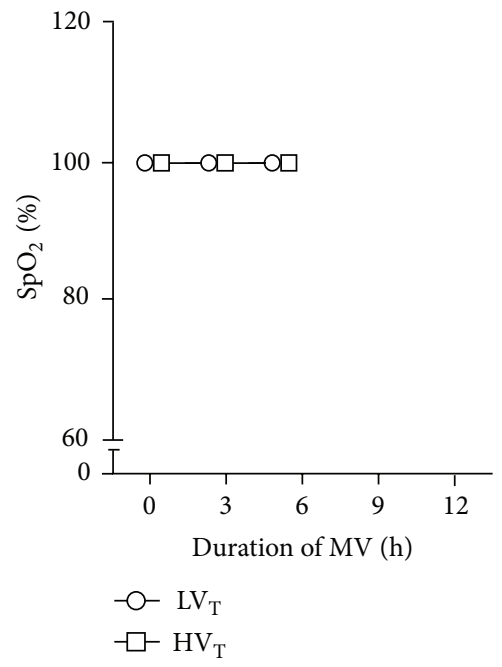

(c)

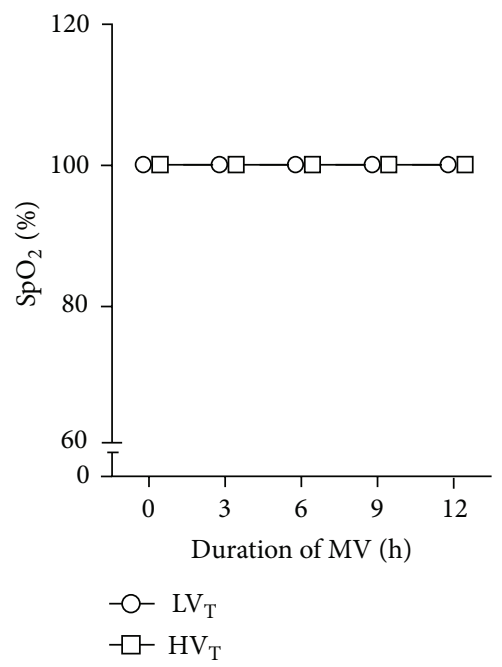

(f)

Figure 1: Hemodynamic parameters. Systolic blood pressures, heart rates, and peripheral oxygen saturation $\left(\mathrm{SpO}_{2}\right)$ remained stable throughout 5 hours $((\mathrm{a})-(\mathrm{c}))$ and 12 hours $((\mathrm{d})-(\mathrm{f}))$ of mechanical ventilation $(\mathrm{MV})$. Data are presented as median (IQR) of 12-15 ((a)-(b), (d)-(e)), or 3-6 ((c), (f)) mice per group (circle $=\mathrm{LV}_{\mathrm{T}}$; square $=\mathrm{HV}_{\mathrm{T}}$ ). $\mathrm{LV}_{\mathrm{T}}, \mathrm{HV}_{\mathrm{T}}=\mathrm{LV}_{\mathrm{T}} / \mathrm{PEEP}$ or $\mathrm{HV}_{\mathrm{T}} / \mathrm{ZEEP}$ ventilator settings. 


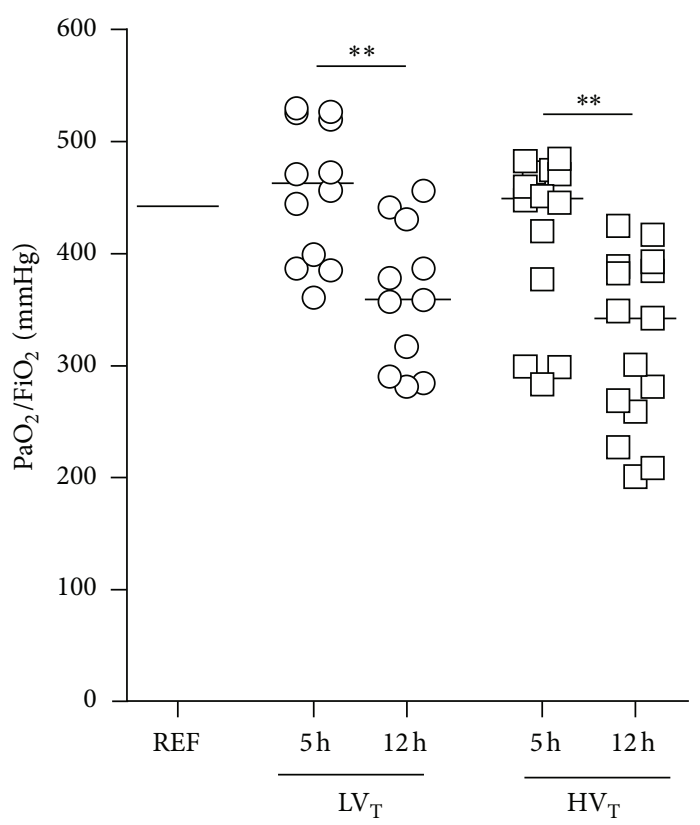

(a)

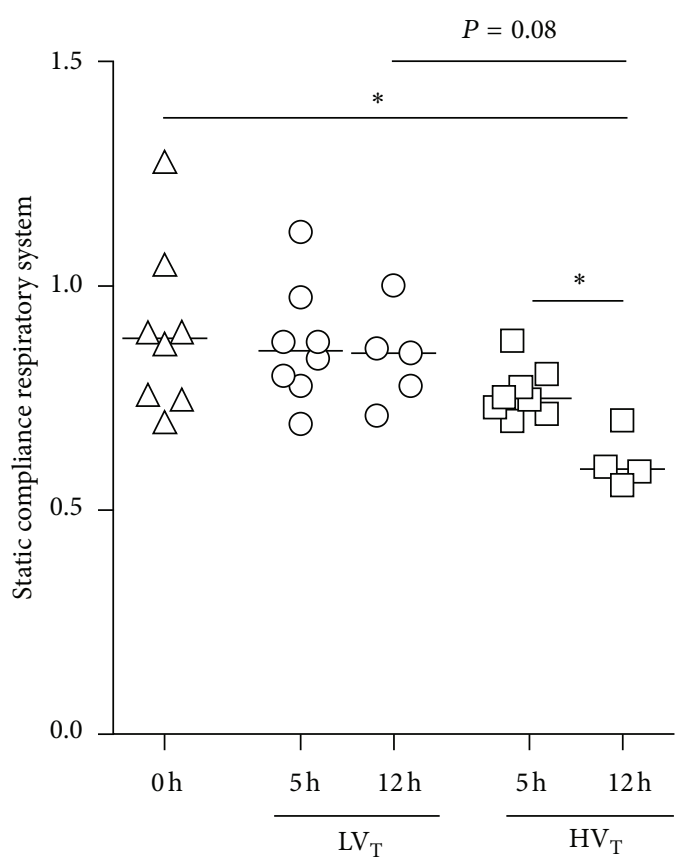

(b)

Figure 2: Respiratory parameters. Lung function is represented by the $\mathrm{PaO}_{2}$ to $\mathrm{FiO}_{2}$ ratio $\left(\mathrm{PaO}_{2} / \mathrm{FiO}\right.$ ) (a) and static compliance of the respiratory system (b). The reference (REF) represents the median $\mathrm{PaO}_{2} / \mathrm{FiO}_{2}$ from 7 mice ventilated with $\mathrm{LV}_{\mathrm{T}} / \mathrm{PEEP}$ for 30 minutes, that is, $442.4 \mathrm{mmHg}$ (396.2 to 501.0) (a) or the combined static compliance of $\mathrm{LV}_{\mathrm{T}} / \mathrm{PEEP}$ and $\mathrm{HV}_{\mathrm{T}} / \mathrm{ZEEP}$-ventilated mice at $t=0 \mathrm{~h}$ (b). The static compliance did not differ between the two groups at $t=0 \mathrm{~h}$. Data are presented as scatter plot (median) of 11-15 (a) or 4-8 (b) mice per group (triangle $=\mathrm{REF}$; circle $=\mathrm{LV}_{\mathrm{T}}$; square $\left.=\mathrm{HV}_{\mathrm{T}}\right) .{ }^{*}$ Illustrates primary statistical analysis $\left({ }^{*} \mathrm{P}<0.05,{ }^{* *} \mathrm{P}<0.01\right)$. NVC $=$ nonventilated controls; $\mathrm{LV}_{\mathrm{T}}, \mathrm{HV}_{\mathrm{T}}=\mathrm{LV}_{\mathrm{T}} / \mathrm{PEEP}$ or $\mathrm{HV}_{\mathrm{T}} / \mathrm{ZEEP}$ ventilator settings; $5 \mathrm{~h}, 12 \mathrm{~h}=5$ or 12 hours of ventilation.

to manufacturer's instructions with bovine serum albumin as standard (OZ Biosciences, Marseille, France). Immunoglobulin (Ig)M levels were measured in BALF by ELISA as previously described [17].

2.9. Statistical Analysis. Data are presented as median (IQR) or scatter plot (median), as appropriate. Since group characteristics did not follow a normal distribution, differences between groups were analyzed by Kruskal-Wallis tests with post hoc Mann-Whitney tests and Bonferroni correction. We first compared 12 hours of MV with 5 hours or NVC $(P$ value for significance was set at 0.0125$)$; next we compared $\mathrm{LV}_{\mathrm{T}} / \mathrm{PEEP}$ with $\mathrm{HV}_{\mathrm{T}} / \mathrm{ZEEP}$ ventilation at 12 hours ( $P$ value for significance was set at 0.01 ). Seven mice were excluded from analysis because of various reasons (i.e., blood in BALF $(n=4)$, unstable blood pressure $(n=1)$, and unreliable cell count measurement $[n=2])$.

\section{Results}

3.1. Hemodynamic and Respiratory Parameters. All mice were ventilated in a pressure-controlled, volume-targeted approach. In $\mathrm{LV}_{\mathrm{T}} / \mathrm{PEEP}$ ventilated mice, $\mathrm{V}_{\mathrm{T}}$ was maintained at $7.0 \mathrm{~mL} / \mathrm{kg}$ by delivering a $P_{\text {plat }}$ of $11.0 \mathrm{cmH}_{2} \mathrm{O}$ throughout 12 hours of MV (Table $1(\mathrm{~A})$ ). In $\mathrm{HV}_{\mathrm{T}} / \mathrm{ZEEP}$ ventilated mice, $\mathrm{V}_{\mathrm{T}}$ was maintained at $15.0 \mathrm{~mL} / \mathrm{kg}$ by delivering a $P_{\text {plat }}$ of $20.0 \mathrm{cmH}_{2} \mathrm{O}$ at 5 hours of MV increasing to $25.5 \mathrm{cmH}_{2} \mathrm{O}$ at 12 hours. All animals survived the experimental procedures throughout 5 or 12 hours of MV. Systolic blood pressures and heart rates remained stable and $\mathrm{SpO}_{2}$ levels remained $\geq 90 \%$ during 5 or 12 hours of $\mathrm{MV}$, independent of ventilation strategy (Figure 1). $\mathrm{PaCO}_{2}, \mathrm{pH}$, base excess, and $\mathrm{HCO}_{3}{ }^{-}$ levels remained within normal to near-normal range in all series of experiments (Table $1(\mathrm{~B})$ ). In both $\mathrm{MV}$ groups, $\mathrm{PaO}_{2}$ to $\mathrm{FiO}_{2}$ ratios were lower after 12 hours of $\mathrm{MV}$ compared to 5 hours (Figure 2(a)). Lung compliances were also lower after 12 hours of MV compared to 5 hours in mice ventilated with $\mathrm{HV}_{\mathrm{T}}$ /ZEEP, but not in mice ventilated with $\mathrm{LV}_{\mathrm{T}} / \mathrm{PEEP}$ (Figure 2(b)).

3.2. Edema Formation and Alveolar-Capillary Permeability. Lung wet to dry ratios were higher after 12 hours of MV compared to 5 hours in mice ventilated with $\mathrm{HV}_{\mathrm{T}} / \mathrm{ZEEP}$, but not in mice ventilated with $\mathrm{LV}_{\mathrm{T}}$ /PEEP (Figure 3(a)). Lung wet to dry ratios showed a negative correlation with lung compliances, especially in $\mathrm{HV}_{\mathrm{T}}$ /ZEEP-ventilated mice (Figure 3(b)). BALF total protein, IgM, and RAGE levels tended to be higher after 12 hours of MV compared to 5 hours in both ventilation groups, although only with statistical significance for IgM in mice ventilated with $\mathrm{HV}_{\mathrm{T}} / \mathrm{ZEEP}$ (Figures 4(a)-4(c)). 


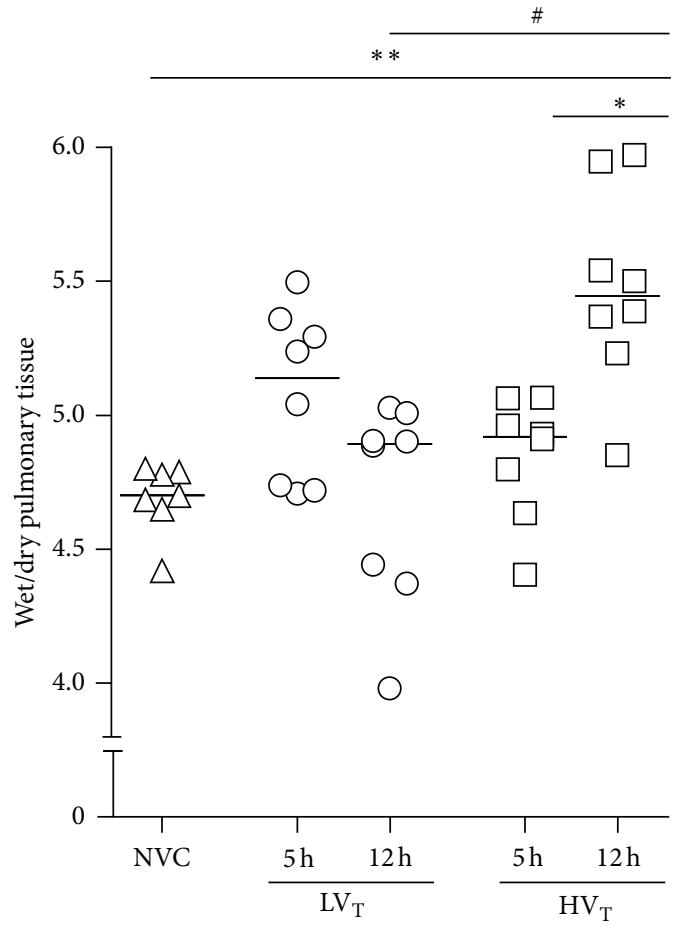

(a)

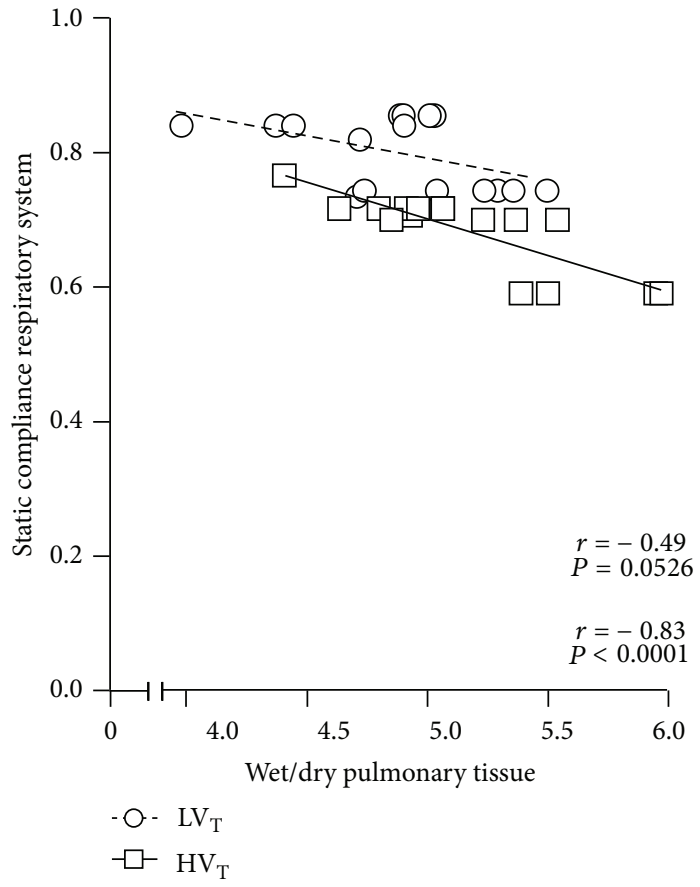

(b)

Figure 3: Edema formation. (a): Edema formation is represented by wet to dry ratios of lung tissue (Wet/Dry). Data are presented as scatter plot (median) of 7-8 mice per group (triangle $=\mathrm{NVC}$; circle $=\mathrm{LV}_{\mathrm{T}}$; square $=\mathrm{HV}_{\mathrm{T}}$ ). ${ }^{*}$ Illustrates primary statistical analysis $\left({ }^{*} P<0.05\right.$, $\left.{ }^{* *} P<0.01\right)$; ${ }^{\#}$ illustrates secondary statistical analysis $\left({ }^{\#} P<0.05\right)$. (b) $\mathrm{In}_{\mathrm{LV}} / \mathrm{PEEP}$ and $\mathrm{HV}_{\mathrm{T}} /$ ZEEP-ventilated mice, correlation analyses were performed between static compliance of respiratory system and wet/dry of pulmonary tissue. Linear correlations, Pearson correlation coefficients $(r)$, and $P$ values are depicted. $\mathrm{NVC}=$ nonventilated controls; $\mathrm{LV}_{\mathrm{T}}, \mathrm{HV}_{\mathrm{T}}=\mathrm{LV}_{\mathrm{T}} / \mathrm{PEEP}$ or $\mathrm{HV}_{\mathrm{T}} / \mathrm{ZEEP}$ ventilator settings; $5 \mathrm{~h}, 12 \mathrm{~h}$ $=5$ or 12 hours of ventilation.

3.3. Cell Infiltration. BALF cell contents were elevated after 12 hours of MV compared to 5 hours, independent of ventilation strategy (Figure 5(a)). BALF neutrophil counts were higher after 12 hours of MV compared to 5 hours in both ventilation groups, although differences did not reach statistical significance when comparing 12 with 5 hours of $\mathrm{MV}$ in mice ventilated with $\mathrm{LV}_{\mathrm{T}}$ /PEEP (Figure 5(b)). BALF macrophage counts were elevated after 12 hours of $\mathrm{MV}$ compared to 5 hours in mice ventilated with $\mathrm{LV}_{\mathrm{T}} / \mathrm{PEEP}$, but not in mice ventilated with $\mathrm{HV}_{\mathrm{T}} /$ ZEEP (Figure 5(c)).

3.4. Inflammatory Mediators. Lung IL- $1 \beta$, IL-6, KC, and MIP2 levels increased after 12 hours of MV compared to NVC in both ventilation groups, except for MIP-2 levels in mice ventilated with $\mathrm{LV}_{\mathrm{T}} /$ PEEP (Figures 6(a)-6(d)). In addition, lung IL-1 $\beta$ and MIP-2 levels were higher after 12 hours of MV compared to 5 hours in mice ventilated with $\mathrm{HV}_{\mathrm{T}} / \mathrm{ZEEP}$, although differences in MIP-2 levels did not reach statistical significance (Figures 6(a) and 6(d)).

3.5. Lung Histopathology. Histopathological changes due to $\mathrm{MV}$ were minor and were recognizable as edema formation and interstitial infiltration of inflammatory cells (Figure 7). Differences in total histopathology score were only observed between 12 hours of $\mathrm{HV}_{\mathrm{T}} / \mathrm{ZEEP}$ ventilation and $\mathrm{NVC}$ (Table 2).

3.6. Differences between MV Strategies. Differences between the two ventilation groups after 12 hours of MV confirm previous findings, with more lung injury with $\mathrm{HV}_{\mathrm{T}} / \mathrm{ZEEP}$ as compared to $\mathrm{LV}_{\mathrm{T}} / \mathrm{PEEP}$ ventilation. These differences include lung wet to dry ratios (Figure 3(a)), BALF total protein levels (Figure 4(a)), BALF RAGE levels (Figure 4(c)), lung IL-1 $\beta$ levels (Figure 6(a)), lung IL-6 levels (Figure 6(b)), lung KC levels (Figure 6(c)), and total histopathology score (Table 2). In contrast, BALF macrophage numbers were higher after 12 hours of $\mathrm{LV}_{\mathrm{T}} / \mathrm{PEEP}$ ventilation compared to 12 hours of $\mathrm{HV}_{\mathrm{T}} / \mathrm{ZEEP}$ ventilation (Figure 5(c)).

\section{Discussion}

The present study shows that the appearance of VILI depends not only on the strategy but also on the duration of MV. 


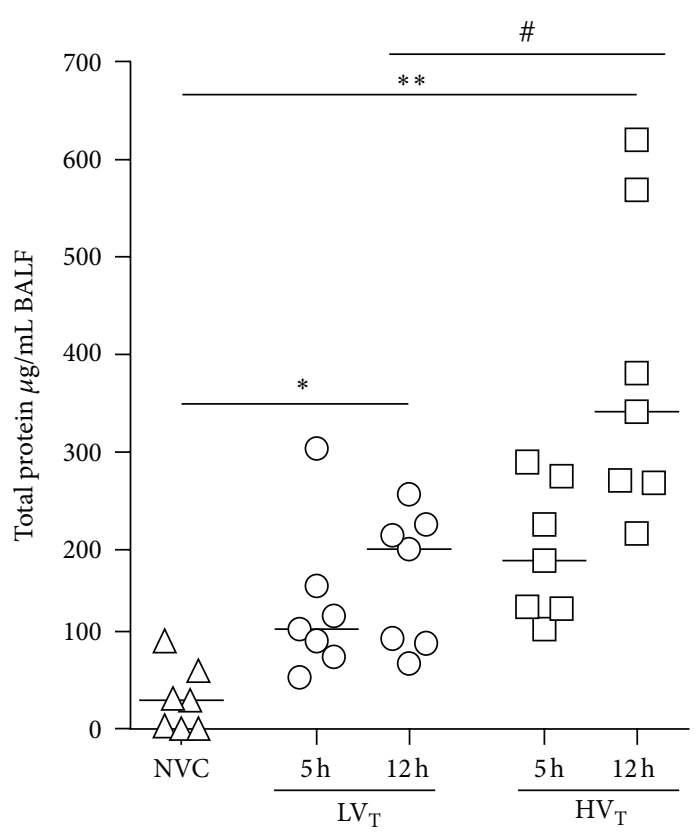

(a)

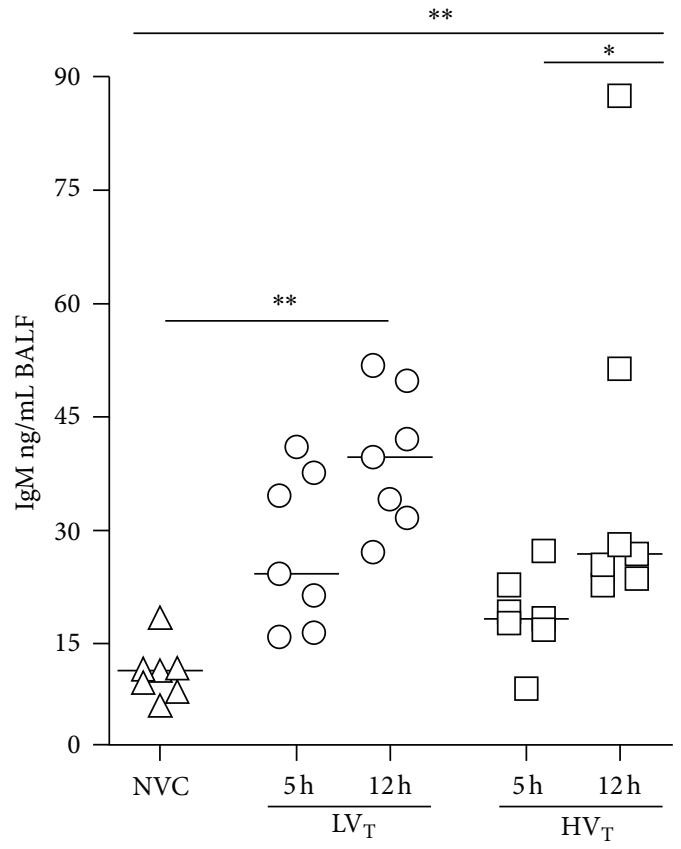

(b)

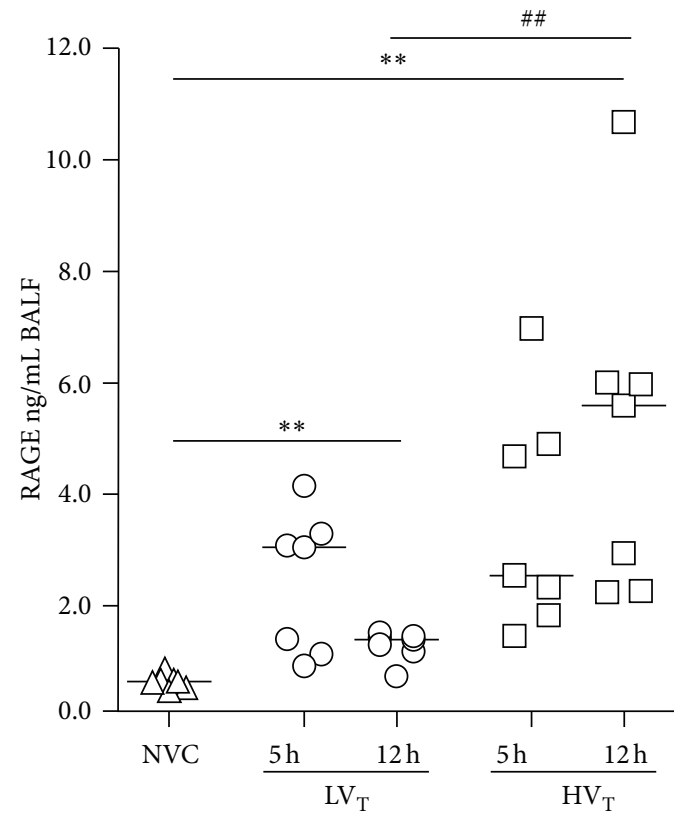

(c)

FIGURE 4: Alveolar-capillary permeability. ((a)-(b)) Alveolar-capillary permeability is represented by total protein and immunoglobulin (Ig)M levels in bronchoalveolar lavage fluid (BALF). (c) Alveolar epithelial type 1 cell injury is represented by receptor for advanced glycation end-

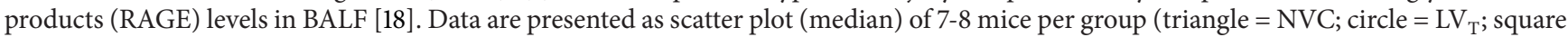
$\left.=\mathrm{HV}_{\mathrm{T}}\right) .{ }^{*}$ Illustrates primary statistical analysis $\left({ }^{*} P<0.05,{ }^{* *} P<0.01\right)$; ${ }^{\#}$ illustrates secondary statistical analysis $\left({ }^{\#} P<0.05\right.$, $\left.{ }^{\# \#} P<0.01\right)$. $\mathrm{NVC}=$ nonventilated controls; $\mathrm{LV}_{\mathrm{T}}, \mathrm{HV}_{\mathrm{T}}=\mathrm{LV}_{\mathrm{T}} / \mathrm{PEEP}$ or $\mathrm{HV}_{\mathrm{T}} / \mathrm{ZEEP}$ ventilator settings; $5 \mathrm{~h}, 12 \mathrm{~h}=5$ or 12 hours of ventilation.

Indeed, well-known characteristics of VILI evolved over time, with longer duration of MV having a greater effect in strategies with $\mathrm{HV}_{\mathrm{T}} / \mathrm{ZEEP}$ than in strategies with $\mathrm{LV}_{\mathrm{T}} / \mathrm{PEEP}$. Moreover, lung injury is even caused by less injurious MV settings when extending the duration.
The results of the present study are, at least in part, in line with previous clinical and animal studies showing that MV has the potential to cause lung injury in healthy lungs. Indeed, two retrospective studies of patients without ARDS at onset of MV suggest that MV with high $V_{T}$ is a risk 


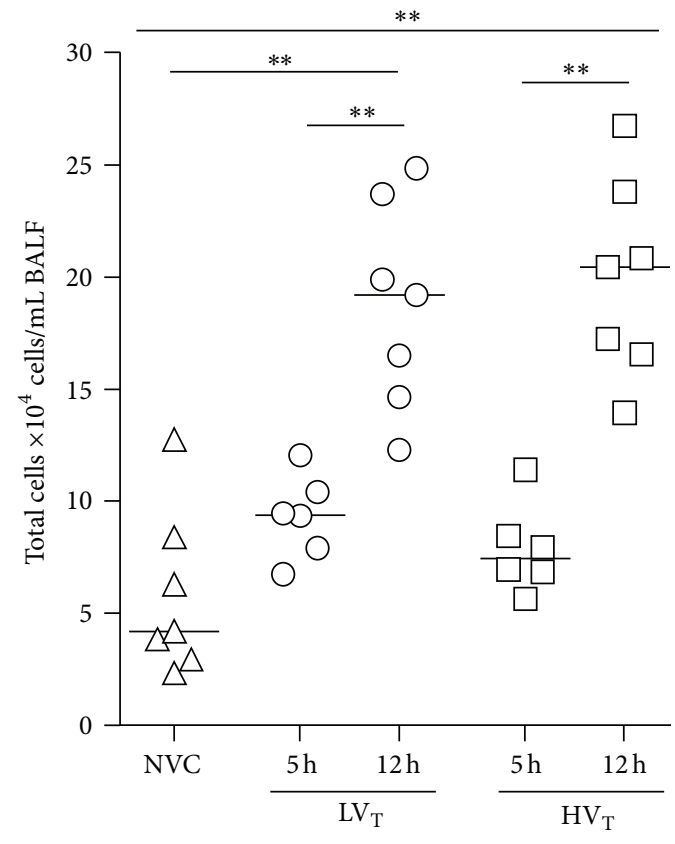

(a)

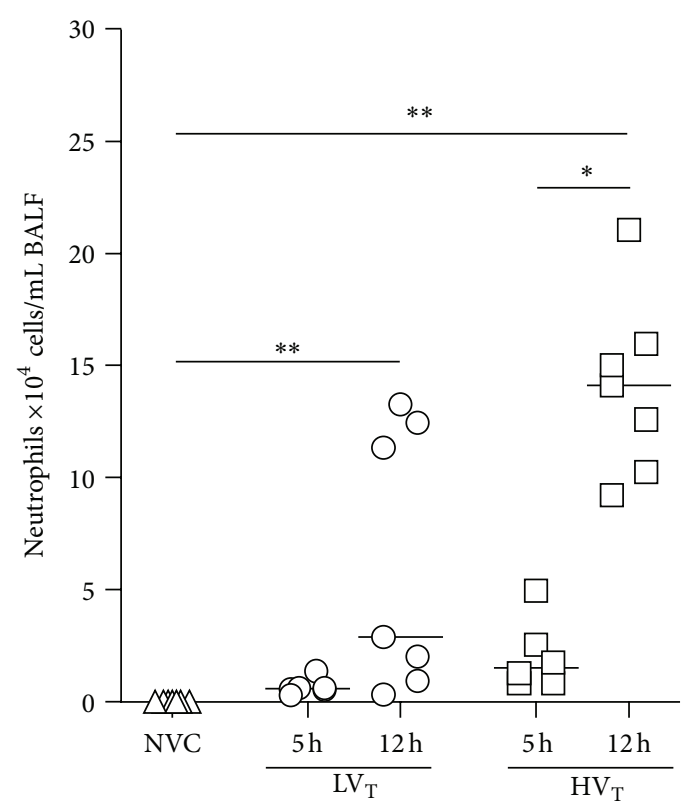

(b)

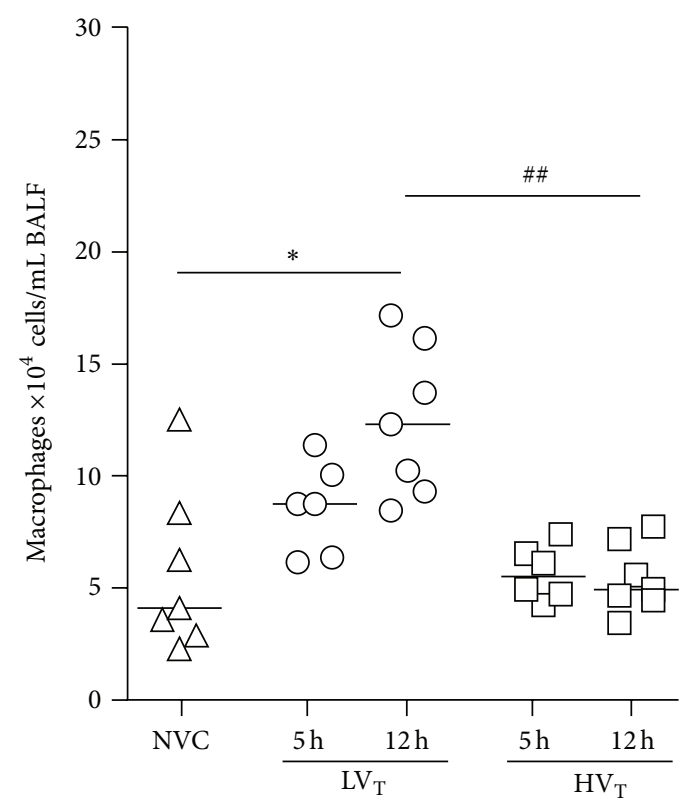

(c)

FIGURE 5: Cell infiltration. (a) Total cell counts were measured in bronchoalveolar lavage fluid (BALF). ((b)-(c)) Differential cell counts were performed on BALF cytospin preparations to determine neutrophil and macrophage infiltration. Data are presented as scatter plot (median) of 6-8 mice per group (triangle $=\mathrm{NVC}$; circle $=\mathrm{LV}_{\mathrm{T}}$; square $=\mathrm{HV}_{\mathrm{T}}$ ). ${ }^{*}$ Illustrates primary statistical analysis $\left({ }^{*} \mathrm{P}<0.05,{ }^{* *} \mathrm{P}<0.01\right.$ ); ${ }^{\#}$ illustrates secondary statistical analysis ( $\left.{ }^{\# \#} \mathrm{P}<0.01\right)$. NVC = nonventilated controls; $\mathrm{LV}_{\mathrm{T}}, \mathrm{HV}_{\mathrm{T}}=\mathrm{LV}_{\mathrm{T}} / \mathrm{PEEP}$ or $\mathrm{HV}_{\mathrm{T}} / \mathrm{ZEEP}$ ventilator settings; $5 \mathrm{~h}, 12 \mathrm{~h}$ $=5$ or 12 hours of ventilation.

factor for developing lung injury $[19,20]$. A more recent randomized controlled trial provides additional evidence by showing that $\mathrm{MV}$ with lower $\mathrm{V}_{\mathrm{T}}$ prevents lung injury in critically ill patients without ARDS at onset of MV [21]. Previous animal studies confirmed that mice with noninjured lungs can develop VILI when exposed to MV [6-10]. Thus, preexisting lung injury is not a prerequisite for the devastating effects of MV. The current finding that even less injurious MV settings can cause lung injury is in line with previous animal studies [11-13]. It should be noted that the majority of small animal investigations studied the effects of MV over relatively short durations. Our data in mice show that the phenotype 


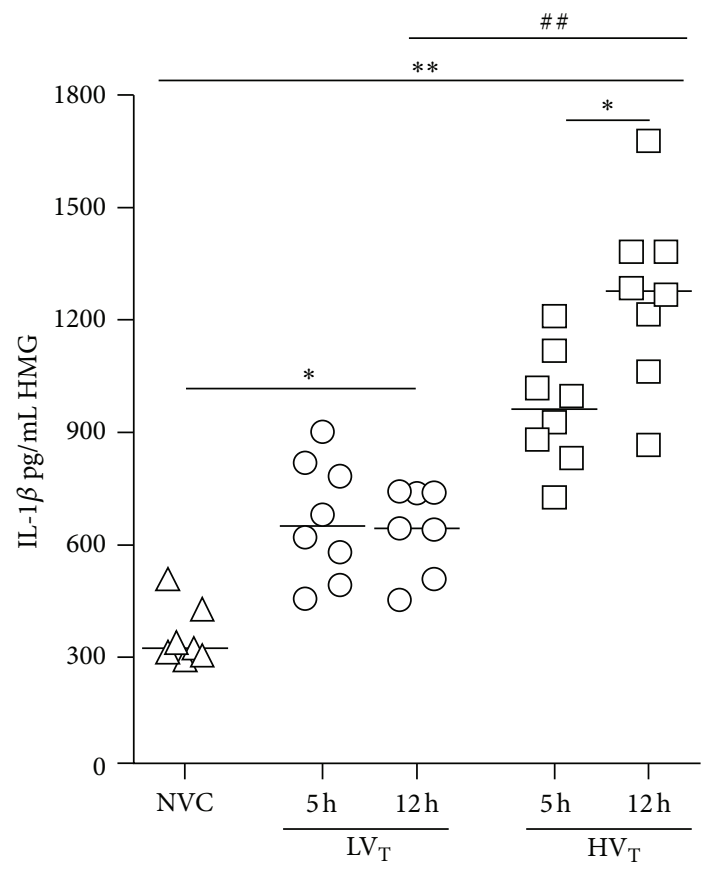

(a)

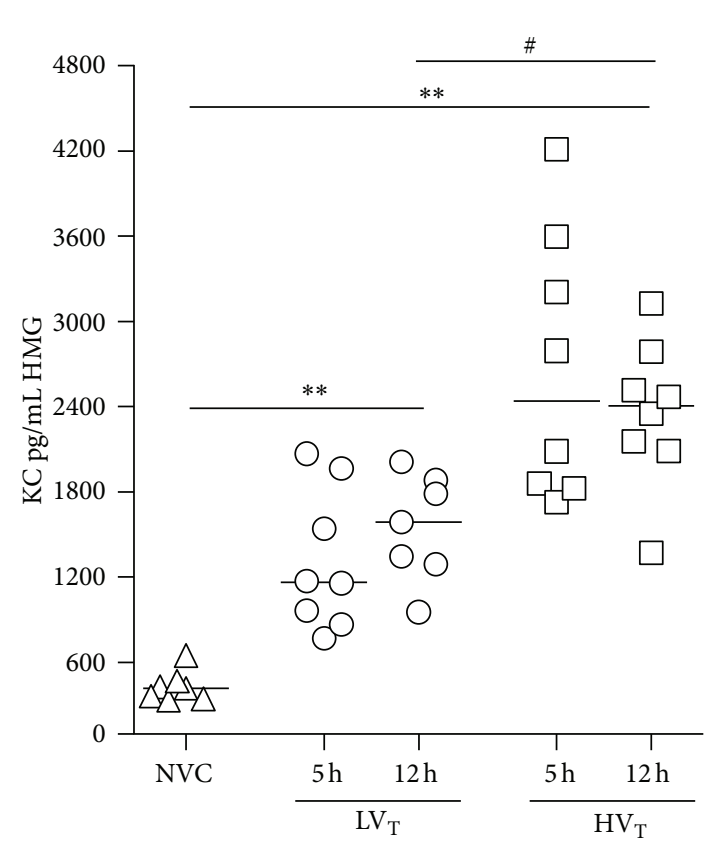

(c)

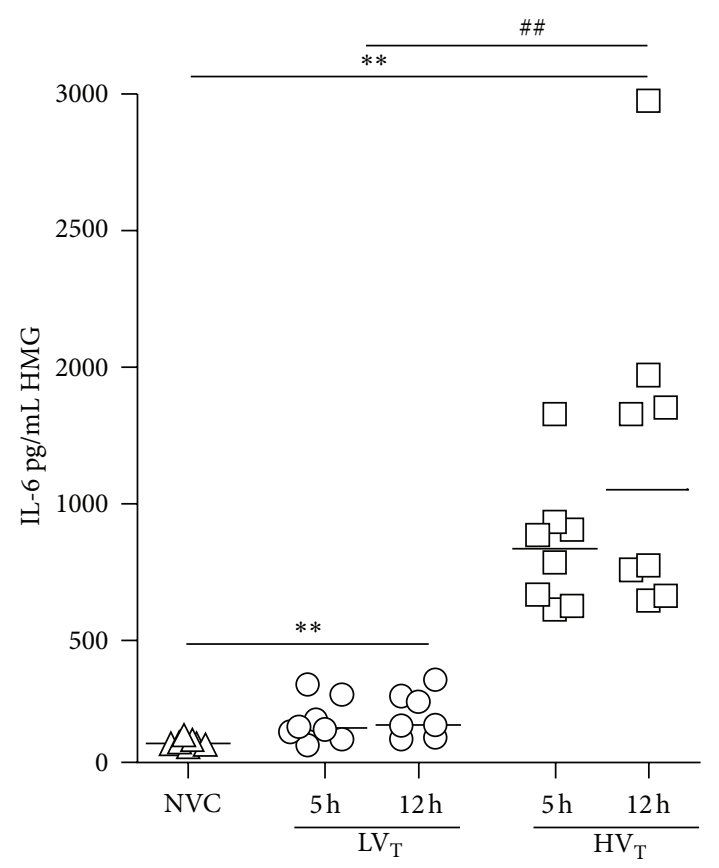

(b)

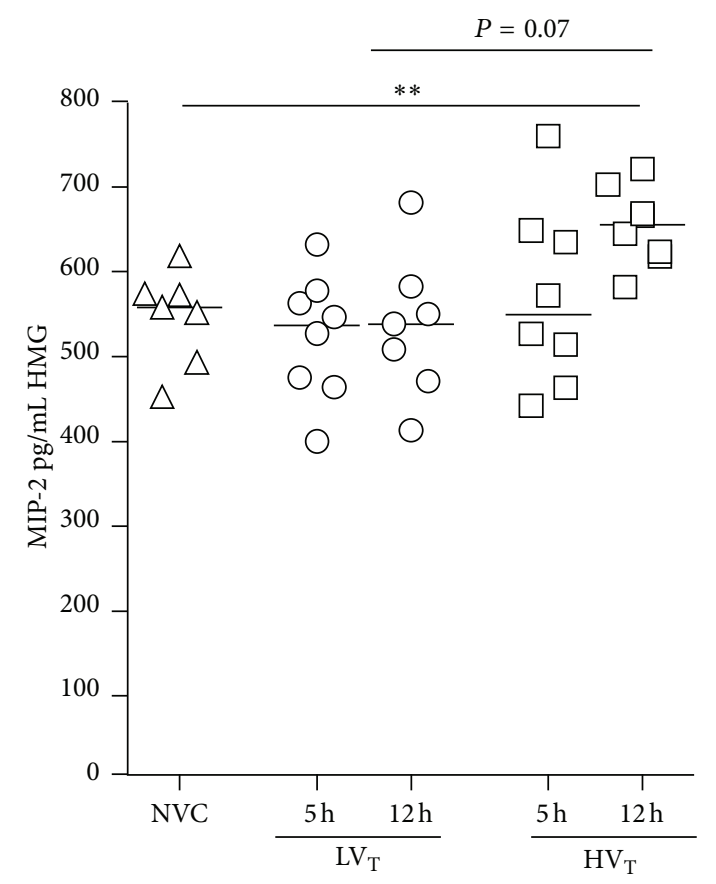

(d)

FIGURE 6: Inflammatory mediators. ((a)-(b)) Protein levels of the proinflammatory cytokines interleukin (IL)-1 $\beta$ and IL-6 were determined in supernatant of total lung homogenates (HMG). ((c)-(d)) In addition, protein levels of the chemotactic cytokines keratinocyte-derived chemokine (KC) and macrophage inflammatory protein (MIP)-2 were determined. Data are presented as scatter plot (median) of 7-8 mice per group (triangle $=\mathrm{NVC}$; circle $=\mathrm{LV}_{\mathrm{T}}$; square $\left.=\mathrm{HV}_{\mathrm{T}}\right) .{ }^{*}$ Illustrates primary statistical analysis $\left({ }^{*} \mathrm{P}<0.05,{ }^{* *} \mathrm{P}<0.01\right) ;{ }^{*}$ illustrates secondary statistical analysis $\left({ }^{\#} \mathrm{P}<0.05,{ }^{\# \#} \mathrm{P}<0.01\right)$. NVC = nonventilated controls; $\mathrm{LV}_{\mathrm{T}}, \mathrm{HV}_{\mathrm{T}}=\mathrm{LV}_{\mathrm{T}} / \mathrm{PEEP}$ or $\mathrm{HV}_{\mathrm{T}} / \mathrm{ZEEP}$ ventilator settings; $5 \mathrm{~h}, 12 \mathrm{~h}$ $=5$ or 12 hours of ventilation. 


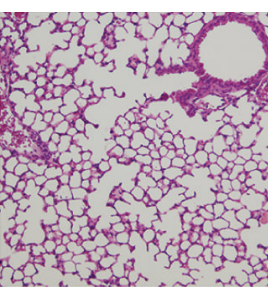

NVC

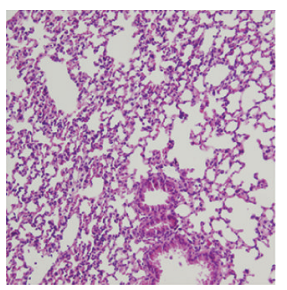

$5 \mathrm{~h} \mathrm{LV}_{\mathrm{T}}$

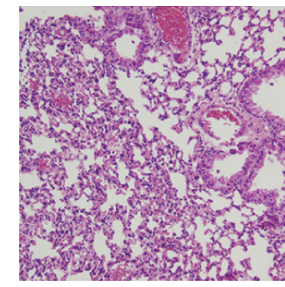

$12 \mathrm{~h} \mathrm{LV}_{\mathrm{T}}$

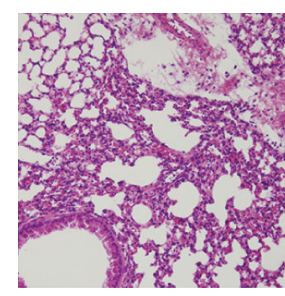

$5 \mathrm{~h} \mathrm{HV}_{\mathrm{T}}$

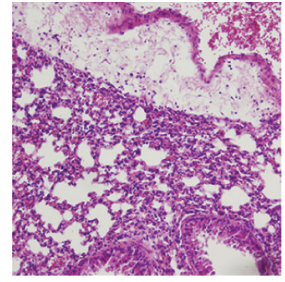

$12 \mathrm{~h} \mathrm{HV}_{\mathrm{T}}$

FiguRE 7: Histopathology. Lung sections were stained with hematoxylin eosin (H\&E) to analyze lung histopathology (magnification 100x). Total histopathology score was determined by the sum of the score for 4 pathologic parameters: (a) edema, (b) hemorrhage, (c) interstitial cell infiltration, and (d) hyaline membranes. $\mathrm{NVC}=$ nonventilated controls; $\mathrm{LV}_{\mathrm{T}}, \mathrm{HV}_{\mathrm{T}}=\mathrm{LV}_{\mathrm{T}} / \mathrm{PEEP}$ or $\mathrm{HV}_{\mathrm{T}} / \mathrm{ZEEP}$ ventilator settings; $5 \mathrm{~h}$, $12 \mathrm{~h}=5$ or 12 hours of ventilation.

TABLE 2: Total histopathology score.

\begin{tabular}{|c|c|c|c|c|c|}
\hline & \multirow{2}{*}{ NVC } & \multicolumn{2}{|c|}{$\mathrm{LV}_{\mathrm{T}}$} & \multicolumn{2}{|c|}{$\mathrm{HV}_{\mathrm{T}}$} \\
\hline & & $5 \mathrm{~h}$ & $12 \mathrm{~h}$ & $5 \mathrm{~h}$ & $12 \mathrm{~h}$ \\
\hline Score & $1.0(0.0$ to 2.0$)$ & 1.5 (1.0 to 2.8$)$ & $1.0(0.0$ to 2.5$)$ & $3.0(2.0$ to 3.8$)$ & $4.0(3.0 \text { to } 4.8)^{* *, \#}$ \\
\hline
\end{tabular}

$\mathrm{NVC}=$ nonventilated control; $\mathrm{LV}_{\mathrm{T}}, \mathrm{HV}_{\mathrm{T}}=$ ventilation with $\mathrm{LV}_{\mathrm{T}} / \mathrm{PEEP}$ or $\mathrm{HV}_{\mathrm{T}} / \mathrm{ZEEP}$ settings; $5 \mathrm{~h}, 12 \mathrm{~h}=5$ or 12 hours of ventilation. Data are presented as median (IQR) of 6-8 mice per group. ${ }^{*}$ illustrates primary statistical analysis $\left({ }^{* *} P<0.01\right.$ versus NVC); ${ }^{*}$ illustrates secondary statistical analysis $\left({ }^{\#} P<0.05\right.$ versus $12 \mathrm{~h} \mathrm{LV}$ ).

of VILI changes with duration of MV. Alveolar-capillary barrier dysfunction and inflammation are early features of VILI. Decrease in $\mathrm{PaO}_{2}$ to $\mathrm{FiO}_{2}$ ratios is observed after a longer duration of $\mathrm{MV}$, whereas neutrophil infiltration was most pronounced after 12 hours of MV. These findings suggest that development of VILI not only progresses but also evolves over time. Thus, small animal investigations using shorterlasting MV may have underestimated the severity and timedependent character of VILI. In large animal models, the evolution of VILI beyond 24 hours has been described before $[14,15]$.

There is convincing evidence that even MV during general anesthesia for surgery has the potential to initiate subtle pulmonary changes [22-26]. In addition, postoperative pulmonary complications add to the morbidity and mortality of surgical patients $[27,28]$ and clinical studies suggest that less injurious MV settings in the perioperative period may reduce postoperative respiratory morbidity [24, 29-31]. As smaller animals have different respiratory mechanisms than humans [32,33] and are less resistant to VILI [34], it should be taken into account that the effect of MV in the experimental setting may not be completely comparable to the clinical setting. Considering the duration of MV used in animal models so far, one could argue that current animal models better reflect the clinical scenario of patients who require general anesthesia for surgery than those who require intensive care. In view of this notion, experimental studies using longer durations of MV may therefore mimic the clinical scenario of patients who need MV for longer-lasting surgical procedures, or patients who need postoperative MV for several hours.

Previous clinical studies clearly show that it makes a difference as far which ventilator settings are being used during the perioperative phase of major surgery $[23,35]$. Although clinical trials about the effects of ventilation strategies in the postoperative setting are lacking, it has been suggested that the use lower $\mathrm{V}_{\mathrm{T}}$ should be considered in all mechanically ventilated patients [3]. Present experimental data may contribute to our understanding of optimal ventilator strategies in patients who need postoperative MV for several hours. This study confirms that extent of VILI is dependent on the used $\mathrm{V}_{\mathrm{T}}$. In addition, this study demonstrates that 5 hours of MV may not be as detrimental as 12 hours of MV. So, it may be important to consider that the aspects of VILI are not only critically influenced by $\mathrm{V}_{\mathrm{T}}$, but also by duration of MV. Indeed, 12 hours of $\mathrm{LV}_{\mathrm{T}} / \mathrm{PEEP}$ ventilation appeared to induce important aspects of VILI as well. Interestingly, increased macrophage numbers were observed after 12 hours of $\mathrm{LV}_{\mathrm{T}} / \mathrm{PEEP}$ ventilation but not after 12 hours of $\mathrm{HV}_{\mathrm{T}} / \mathrm{ZEEP}$ ventilation. The failure to recover BALF macrophages after 12 hours of $\mathrm{HV}_{\mathrm{T}}$ /ZEEP could suggest macrophage activation and adhesion to lung tissue which may account for orchestrating the increase in proinflammatory mediators and recruitment of neutrophils. Recent studies, however, revealed the importance of macrophages in the termination and resolution of inflammation [36]. Therefore, an alternative explanation is that the presence of more macrophages after 12 hours of $\mathrm{LV}_{\mathrm{T}} / \mathrm{PEEP}$ ventilation could play a protective role in the development of VILI. It has been previously shown that macrophages are involved in tissue repair and as a result capable of restoring lung barrier integrity [36]. Supporting the latter explanation, a negative correlation was found between BALF macrophage numbers and wet to dry ratios in $\mathrm{LV}_{\mathrm{T}} / \mathrm{PEEP}$-ventilated mice (Pearson $r=-0.85$ with $P=0.0003$ ). Future studies need to address the differential effects of MV settings and duration on BALF macrophage numbers and evaluate the exact role of macrophages in the development of VILI. Another negative correlation was found between lung wet to dry ratios and compliances in both MV groups. This finding supports the rationale that 
accumulation of interstitial and alveolar edema decreases compliance of the respiratory system as gas in small airways becomes displaced with fluid [37]. Lung compliance and wet to dry ratio were only altered in mice ventilated with $\mathrm{HV}_{\mathrm{T}}$ /ZEEP for 12 hours, which may reflect that more time is required for enhanced microvascular permeability and subsequent fluid filtration into the interstitial and alveolar space.

The present study knows several limitations. First, clinically relevant $\mathrm{V}_{\mathrm{T}}$ that closely reflect current MV practice in critically ill patients were used. Within this range of clinically relevant $\mathrm{V}_{\mathrm{T}}$, we restricted the experimental design to a "less" and "more" injurious MV strategy $\left(\mathrm{LV}_{\mathrm{T}} / \mathrm{PEEP}\right.$ and $\mathrm{HV}_{\mathrm{T}}$ /ZEEP, resp.). Second, it has been described that mice have different respiratory mechanisms than humans $[32,33]$. Moreover, smaller species have less resistance to VILI than larger species [34]. Therefore, a tidal volume of $7 \mathrm{~mL} / \mathrm{kg}$ may have a greater effect in mice than in humans, where it is considered a protective ventilator setting. In addition, the lifespan of mice is much shorter compared to that of humans making 12 hours of MV relatively longer in mice than in humans. These differences in physiology may hamper the translation of current results to the human situation. Third, the analysis was restricted to some well-known characteristics of VILI such as the proinflammatory response, immune cell infiltration, alveolar-capillary permeability, and lung function. And fourth, the effects of MV were studied in otherwise healthy mice. The effects of longer duration of MV may be even more distinct in mice with lung injury.

\section{Conclusions}

In healthy mice, longer duration of MV aggravates important aspects of VILI compared to shorter-lasting MV or spontaneous breathing, with the phenotype of VILI changing over time. Furthermore, even less injurious ventilator settings may induce important aspects of VILI after 12 hours of MV. Thus, when interpreting data from animal studies, it is important to realize that deleterious effects of MV are dependent not only on its strategy but also on its duration.

\section{Acknowledgments}

The authors thank for expert assistance with the statistical analysis: Dr. J. M. Binnekade (statistician), Department of Intensive Care, Academic Medical Center, University of Amsterdam, Amsterdam, the Netherlands.

\section{References}

[1] A. Malhotra, "Low-tidal-volume ventilation in the acute respiratory distress syndrome," The New England Journal of Medicine, vol. 357, no. 11, pp. 1113-1120, 2007.

[2] C. Putensen, N. Theuerkauf, J. Zinserling, H. Wrigge, and P. Pelosi, "Meta-analysis: ventilation strategies and outcomes of the acute respiratory distress syndrome and acute lung injury," Annals of Internal Medicine, vol. 151, no. 8, pp. 566-576, 2009.

[3] M. J. Schultz, J. J. Haitsma, A. S. Slutsky, and O. Gajic, "What tidal volumes should be used in patients without acute lung injury?” Anesthesiology, vol. 106, no. 6, pp. 1226-1231, 2007.
[4] A. S. Neto, S. O. Cardoso, J. A. Manetta et al., "Association between use of lung protective ventilation with lower tidal volumes and risk of acute lung injury, mortality, pulmonary infection and atelectasis-a meta-analysis," Journal of the American Medical Association, vol. 308, no. 16, pp. 1651-1659, 2012.

[5] D. Dreyfuss and G. Saumon, "Ventilator-induced lung injury: lessons from experimental studies," American Journal of Respiratory and Critical Care Medicine, vol. 157, no. 1, pp. 294-323, 1998.

[6] J. A. Belperio, M. P. Keane, M. D. Burdick et al., "Critical role for $\mathrm{CXCR}_{2}$ and $\mathrm{CXCR}_{2}$ ligands during the pathogenesis of ventilator-induced lung injury," Journal of Clinical Investigation, vol. 110, no. 11, pp. 1703-1716, 2002.

[7] I. B. Copland, F. Martinez, B. P. Kavanagh et al., "High tidal volume ventilation causes different inflammatory responses in newborn versus adult lung," American Journal of Respiratory and Critical Care Medicine, vol. 169, no. 6, pp. 739-748, 2004.

[8] J. J. Haitsma, S. Uhlig, S. J. Verbrugge, R. Göggel, D. L. H. Poelma, and B. Lachmann, "Injurious ventilation strategies cause systemic release of IL-6 and MIP-2 in rats in vivo," Clinical Physiology and Functional Imaging, vol. 23, no. 6, pp. 349-353, 2003.

[9] M. R. Wilson, S. Choudhury, M. E. Goddard, K. P. O’Dea, A. G. Nicholson, and M. Takata, "High tidal volume upregulates intrapulmonary cytokines in an in vivo mouse model of ventilator-induced lung injury," Journal of Applied Physiology, vol. 95, no. 4, pp. 1385-1393, 2003.

[10] M. R. Wilson, S. Choudhury, and M. Takata, "Pulmonary inflammation induced by high-stretch ventilation is mediated by tumor necrosis factor signaling in mice," American Journal of Physiology, vol. 288, no. 4, pp. L599-L607, 2005.

[11] P. M. Cobelens, B. P. van Putte, A. Kavelaars, C. J. Heijnen, and J. Kesecioglu, "Inflammatory consequences of lung ischemiareperfusion injury and low-pressure ventilation," Journal of Surgical Research, vol. 153, no. 2, pp. 295-301, 2009.

[12] M. Vaneker, F. J. Halbertsma, J. van Egmond et al., "Mechanical ventilation in healthy mice induces reversible pulmonary and systemic cytokine elevation with preserved alveolar integrity: an in vivo model using clinical relevant ventilation settings," Anesthesiology, vol. 107, no. 3, pp. 419-426, 2007.

[13] E. K. Wolthuis, A. P. Vlaar, G. Choi, J. J. Roelofs, N. P. Juffermans, and M. J. Schultz, "Mechanical ventilation using non-injurious ventilation settings causes lung injury in the absence of pre-existing lung injury in healthy mice," Critical Care, vol. 13, no. 1, article R1, 2009.

[14] S. Mandava, T. Kolobow, G. Vitale et al., "Lethal systemic capillary leak syndrome associated with severe ventilator-induced lung injury: an experimental study," Critical Care Medicine, vol. 31, no. 3, pp. 885-892, 2003.

[15] K. Tsuno, P. Prato, and T. Kolobow, "Acute lung injury from mechanical ventilation at moderately high airway pressures," Journal of Applied Physiology, vol. 69, no. 3, pp. 956-961, 1990.

[16] M. A. Hegeman, M. P. Hennus, M. van Meurs et al., "Angiopoietin-1 treatment reduces inflammation but does not prevent ventilator-induced lung injury," PLoS ONE, vol. 5, no. 12, Article ID e15653, 2010.

[17] R. M. Reijmers, R. W. J. Groen, A. Kuil et al., "Disruption of heparan sulfate proteoglycan conformation perturbs B-cell maturation and APRIL-mediated plasma cell survival," Blood, vol. 117, no. 23, pp. 6162-6171, 2011.

[18] T. Uchida, M. Shirasawa, L. B. Ware et al., "Receptor for advanced glycation end-products is a marker of type I cell 
injury in acute lung injury," American Journal of Respiratory and Critical Care Medicine, vol. 173, no. 9, pp. 1008-1015, 2006.

[19] O. Gajic, S. I. Dara, J. L. Mendez et al., "Ventilator-associated lung injury in patients without acute lung injury at the onset of mechanical ventilation," Critical Care Medicine, vol. 32, no. 9, pp. 1817-1824, 2004.

[20] O. Gajic, F. Frutos-Vivar, A. Esteban, R. D. Hubmayr, and A. Anzueto, "Ventilator settings as a risk factor for acute respiratory distress syndrome in mechanically ventilated patients," Intensive Care Medicine, vol. 31, no. 7, pp. 922-926, 2005.

[21] R. M. Determann, A. Royakkers, E. K. Wolthuis et al., "Ventilation with lower tidal volumes as compared with conventional tidal volumes for patients without acute lung injury: a preventive randomized controlled trial," Critical Care, vol. 14, no. 1, article R1, 2010.

[22] G. Choi, E. K. Wolthuis, P. Bresser et al., "Mechanical ventilation with lower tidal volumes and positive end-expiratory pressure prevents alveolar coagulation in patients without lung injury," Anesthesiology, vol. 105, no. 4, pp. 689-695, 2006.

[23] M. Licker, J. Diaper, Y. Villiger et al., "Impact of intraoperative lung-protective interventions in patients undergoing lung cancer surgery," Critical Care, vol. 13, no. 2, article R41, 2009.

[24] P. Michelet, X. B. D’Journo, A. Roch et al., "Protective ventilation influences systemic inflammation after esophagectomy: a randomized controlled study," Anesthesiology, vol. 105, no. 5, pp. 911-919, 2006.

[25] E. K. Wolthuis, G. Choi, M. C. Dessing et al., "Mechanical ventilation with lower tidal volumes and positive end-expiratory pressure prevents pulmonary inflammation in patients without preexisting lung injury," Anesthesiology, vol. 108, no. 1, pp. 46$54,2008$.

[26] E. Zupancich, D. Paparella, F. Turani et al., "Mechanical ventilation affects inflammatory mediators in patients undergoing cardiopulmonary bypass for cardiac surgery: a randomized clinical trial," Journal of Thoracic and Cardiovascular Surgery, vol. 130, no. 2, pp. 378-383, 2005.

[27] A. M. Arozullah, J. Daley, W. G. Henderson, and S. F. Khuri, "Multifactorial risk index for predicting postoperative respiratory failure in men after major noncardiac surgery," Annals of Surgery, vol. 232, no. 2, pp. 242-253, 2000.

[28] G. W. Smetana, V. A. Lawrence, and J. E. Cornell, "Preoperative pulmonary risk stratification for noncardiothoracic surgery: systematic review for the American College of Physicians," Annals of Internal Medicine, vol. 144, no. 8, pp. 581-595, 2006.

[29] M. A. Chaney, M. P. Nikolov, B. P. Blakeman, and M. Bakhos, "Protective ventilation attenuates postoperative pulmonary dysfunction in patients undergoing cardiopulmonary bypass," Journal of Cardiothoracic and Vascular Anesthesia, vol. 14, no. 5, pp. 514-518, 2000.

[30] P. G. Lee, C. M. Helsmoortel, S. M. Cohn, and M. P. Fink, "Are low tidal volumes safe?" Chest, vol. 97, no. 2, pp. 430-434, 1990.

[31] M. Yang, H. J. Ahn, K. Kim et al., "Does a protective ventilation strategy reduce the risk of pulmonary complications after lung cancer surgery?: a randomized controlled trial," Chest, vol. 139, no. 3, pp. 530-537, 2011.

[32] S. E. Soutiere and W. Mitzner, "On defining total lung capacity in the mouse," Journal of Applied Physiology, vol. 96, no. 5, pp. 1658-1664, 2004.

[33] G. R. Zosky, T. Z. Janosi, A. Adamicza et al., "The bimodal quasistatic and dynamic elastance of the murine lung," Journal of Applied Physiology, vol. 105, no. 2, pp. 685-692, 2008.
[34] P. Caironi, T. Langer, E. Carlesso et al., "Time to generate ventilator-induced lung injury among mammals with healthy lungs: a unifying hypothesis," Intensive Care Medicine, vol. 37, no. 12, pp. 1913-1920, 2011.

[35] F. Lellouche, S. Dionne, S. Simard et al., "High tidal volumes in mechanically ventilated patients increase organ dysfunction after cardiac surgery," Anesthesiology, vol. 116, no. 5, pp. 10721082, 2012.

[36] S. Herold, K. Mayer, and J. Lohmeyer, "Acute lung injury: how macrophages orchestrate resolution of inflammation and tissue repair," Frontiers in Immunology, vol. 2, article 65, 2011.

[37] J. C. Parker and M. I. Townsley, "Evaluation of lung injury in rats and mice," American Journal of Physiology, vol. 286, no. 2, pp. L231-L246, 2004. 


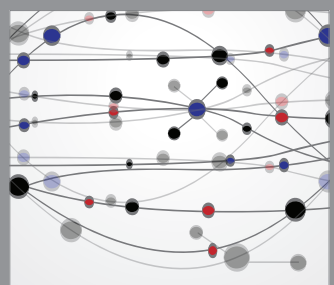

The Scientific World Journal
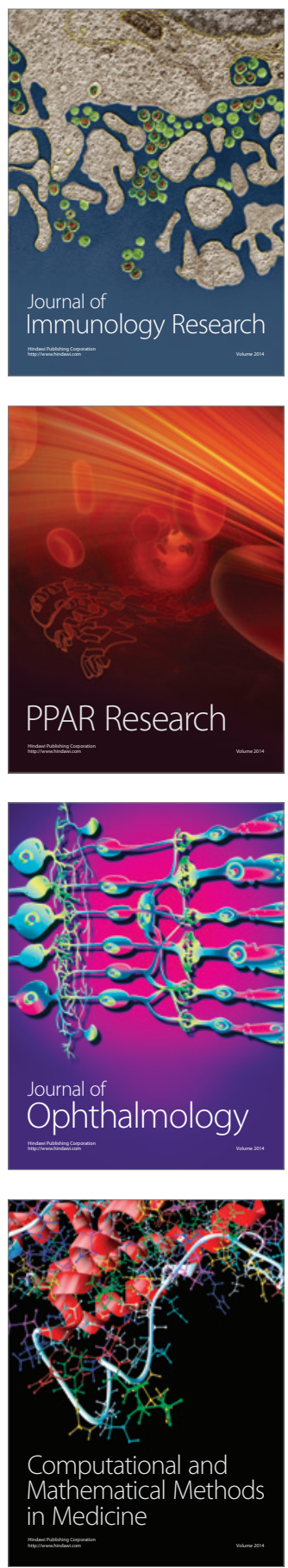

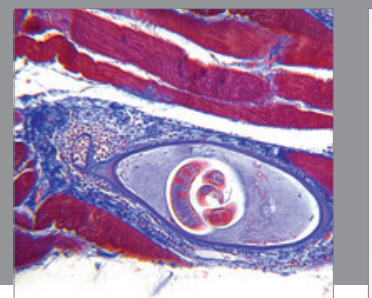

Gastroenterology

Research and Practice
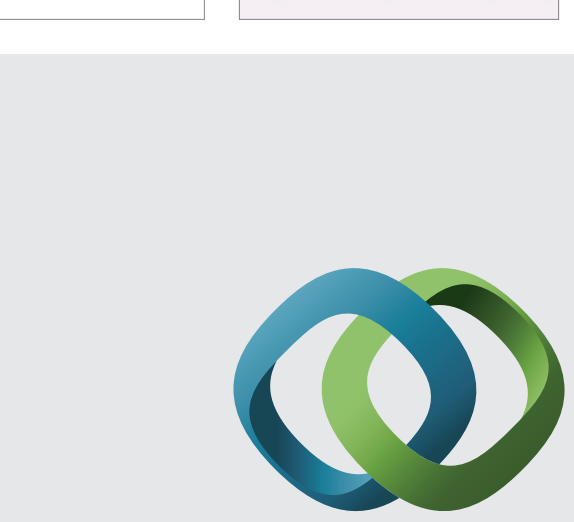

\section{Hindawi}

Submit your manuscripts at

http://www.hindawi.com
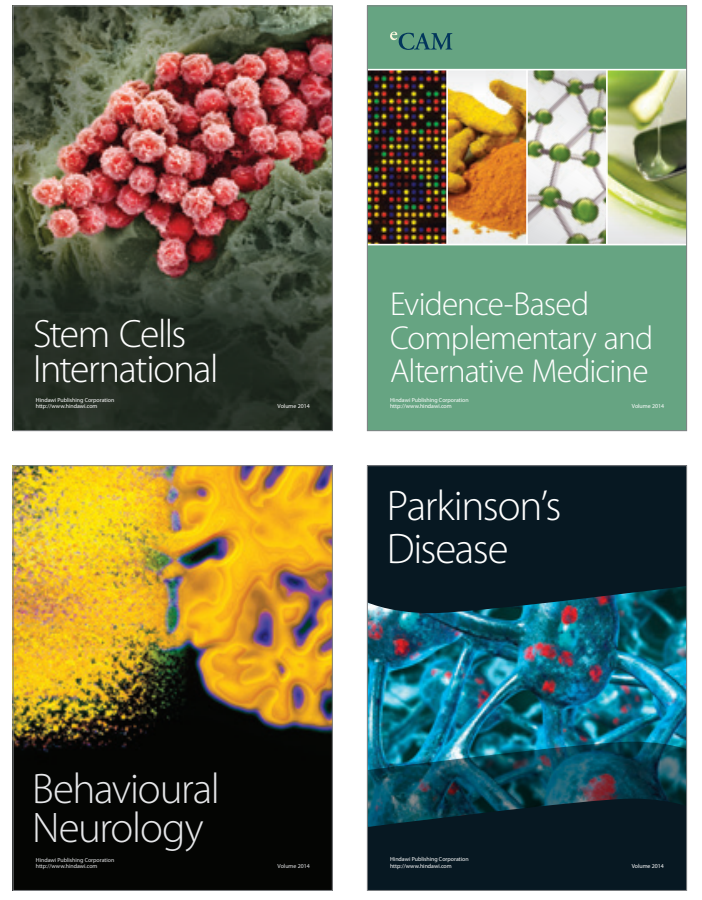
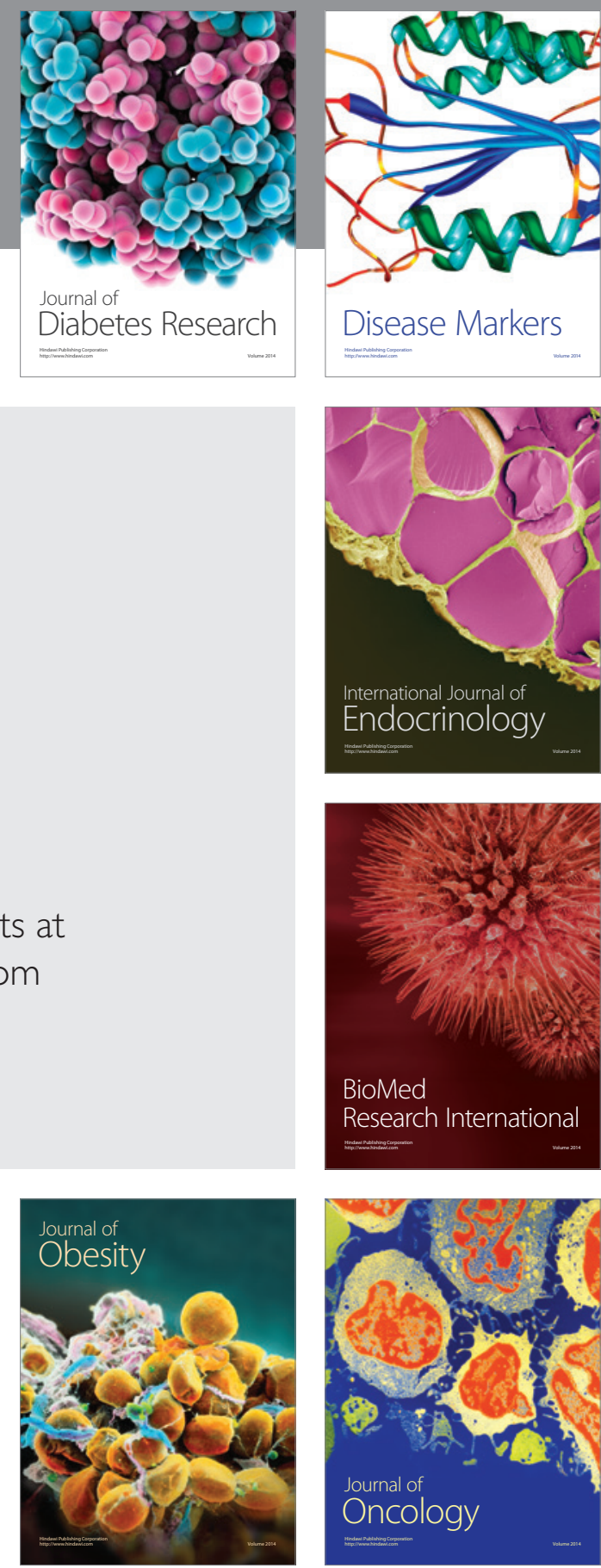

Disease Markers
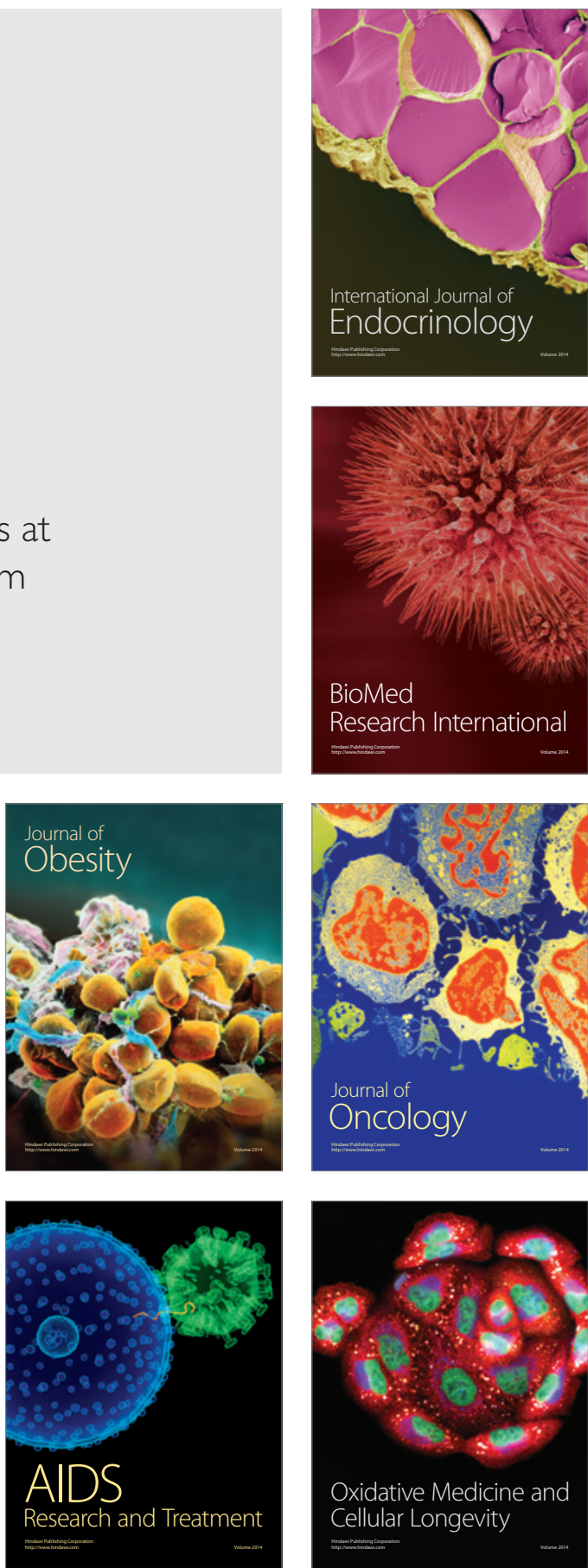